\title{
AN UPDATED LIST OF LIVERWORTS OF THE SEVERNAYA ZEMLYA ARCHIPELAGO (EAST SIBERIAN HIGH ARCTIC) WITH DESCRIPTION OF A NEW SPECIES, SCAPANIA MATVEYEVAE ОБНОВЛЕННЫЙ СПИСОК ПЕЧЕНОЧНИКОВ АРХИПЕЛАГА СЕВЕРНАЯ ЗЕМЛЯ (ВЫСОКАЯ ВОСТОЧНОСИБИРСКАЯ АРКТИКА) С ОПИСАНИЕМ НОВОГО ВИДА, SСАРАNIA MATVЕYЕVАЕ
}

\author{
ALEXEY D. POTEMKIN ${ }^{1}$ \\ АЛЕКСЕЙ Д. ПОТЁМКИН ${ }^{1}$
}

\begin{abstract}
The present data on taxonomic composition, occurrence and reproduction of liverworts of the Severnaya Zemlya Archipelago, East Siberian High Arctic, are compiled and analyzed. Totally 49 species are recorded for the archipelago. Four species, including Scapania matveyevae sp. nov., are reported for the first time for the archi pelago. Illustrated description, differentiation and consideration of taxonomic position of S. matveyevae are provided.

Резюме

В статье обобщены и проанализированы современные данные о таксономическом составе, встречаемости и воспроизведении печеночников Северной Земли. В целом 49 видов приводится для архипелага. Четыре вида, включая новый для науки вид Scapania matveyevae, указываются впервые для Северной Земли. В работе приводится иллюстрированное описание нового вида, характеризуются его отличительные признаки и обсуждается таксономическое положение.
\end{abstract}

\section{INTRODUCTION}

The history of liverwort study of the Severnaya Zemlya Archi pelago counts over 60 years. The first report on the bryophyte flora of the archipelago by L. I. Savicz (1936) was based on the collections of V. P. Savicz gathered in 1930 in the course of the expedition on the icebreaker "Georgy Sedov" to the Sedova Archipelago (former Sergeya Kameneva Islands, $79^{\circ} 24-25^{\prime} \mathrm{N}-91^{\circ} 03-40^{\prime} \mathrm{E}$ ) belonging to the Severnaya Zemlya Archipelago. That report included the only liverwort species, Blepharostoma trichophyllum. Later Potemkin published extensive additions to the flora based on the collections by Irina N. Safronova (Andreev et al., 1993) and by Nadezhda V. Matveyeva (Potemkin, 1999). Study of purposeful liverwort collections by Matveyeva, gathered in the Bol'shevik Island resulted in the extension of the former floristic list to 49 species. Four of these are recorded for the first time for the ar- chipelago,including Scapania matveyevae sp. nov.

Present data on the liverwort flora of the archi pelago remains to be incomplete because: (1) no liverwort collections were made on the territory of the archi pelago by professional hepaticologists; (2) the present data on the flora concerned mostly the flora of southernmost island of the archi pelago,Bol'shevik Island,that is still insufficiently studied (Fig. 1); (3) not all known collections from the territory of the archi pelago were investigated.

The goal of this paper is to list the present data on the liverwort flora of the archipelago with references to apparently little-known previous publications in Russian and to provide the description of the new species, Scapania matveyevae.

\section{LIST OF SPECIES}

In the species list the following abbreviations are used: B - Bol'shevik Island (1 - An-

1 - V.L. Komarov Botanical Institute of the Russian Academy of Sciences, 2 Prof. Popov str., St. Petersburg 197376 Russia - Ботанический институт им. В. Л. Комарова РАН, проф. Попова, 2, Санкт-Петербург 197376 Россия. 


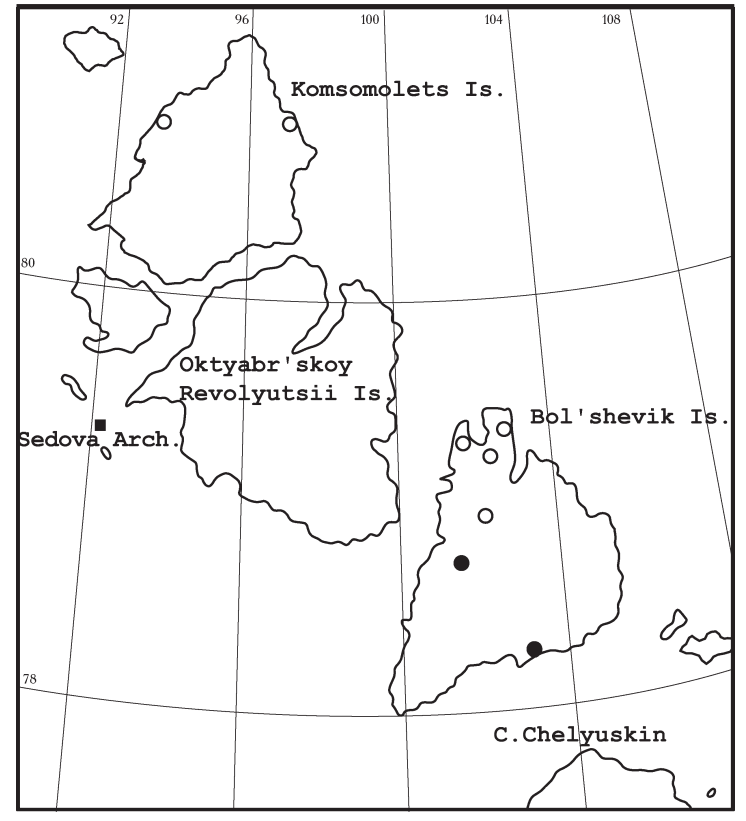

dreev \& al., 1993; 2 - Potemkin, 1999; 3 - previously unpublished collections gathered in southern part of Bol'shevik Island by Matveyeva in 1998); K Komsomolets Island (all from Andreev et al. 1993); S - Sedov Archipelago (from Savicz, 1936). Occurrence is as follows: $r-$ rare, found 1-2 times; ls - locally sporadic, found 3-7 times in one or similar plant communities; s - sporadic, found 3-7 times in different communities; lc - locally common, found in one or similar plant communities more than 7 times; $\mathrm{c}-$ common, found over 7 times in different communities. Reproductive organs are mentioned when present. The arrangement of species is after Konstantinova \& al. (1992).

ANEURACEAE

Aneura pinguis (L.) Dum. - B (3); r.

TRICHOCOLEACEAE

Blepharostoma trichophyllum (L.) Dum. var. brevirete Bryhn \& Kaal. - B (1-3), S; c.

\section{ANTHELIACEAE}

Anthelia juratzkana (Limr.) Trev. - B (1-3), K; s; per.

\section{JUNGERMANNIACEAE}

Tetralophozia setiformis (Ehrh.) Schljak. - B (2); r. Barbilophozia barbata (Schreb.) Loeske - B (1-2); r.

B. binsteadii (Kaal.) Loeske - B (2); r.

B. hyperborea (Schust.) Potemkin - B (1-3); s.

B. quadriloba (Lindb.) Loeske - B (1-3); s.

Lophozia excisa (Dicks.) Dum. var. excisa - B (13); s; gem.

- var. succulenta Schust. \& Damsh. - B (2); r; gem.
Fig. 1. Severnaya Zemlya Archipelago - collection localities: square - Savicz, 1930; open circle - Safronova, 1991; solid circle - Matveyeva, 1997, 1998.

L. heterocolpos (Hartm.) M. A. Howe - B (1,3); s.

L. jurensis K. Muell. - B (1-3); s; gem, ○7, ㅇ.

L. longiflora (Nees) Schiffn. - B (2); r.

L. major (C. Jens.) Schljak. - B (2-3); s; gem.

L. sp. cf. L. pellucida Schust. var. minor Schust. - B

(1); r; juv. gem.

L. ventricosa (Dicks.) Dum. var. confusa Schust. ( $L$. sp. cf. L. savicziae Schljak. [in Andreev et al. (1993: 75)]) - B (1-3); s; gem.

L. sp. cf. L. wenzelii (Nees) Steph. - B (3); r.

Anastrophyllum cavifolium (Buch \& S. Arnell) Lammes - B (2); r.

A. minutum (Schreb.) Schust. (incl. "var. grandis" (Lindb.) Schust.) - B (1-3); c; per, $0^{7}$.

Tritomaria quinquedentata (Huds.) Buch var. quinquedentata - B (1-3); c; per.

var. grandigemma Potemkin - B (2-3); s; gem.

Jungermannia polaris Lindb. - B $(1,3)$; s.

GYMNOMITRIACEAE

Prasanthus suecicus (Gott.) Lindb. - B (2-3); s; per. Marsupella arctica (Berggr.) Bryhn \& Kaal. - B (2-3); lc.

M. sprucei (Limpr.) H. Bern. - B (3); r.

Gymnomitrion apiculatum (Schiffn.) K. Muell. - B (2-3); r.

G. concinnatum (Lightf.) Corda - B (1-3); c; fr.

G. corallioides Nees - B (1-3); c; fr.

SCAPANIACEAE

Scapania brevicaulis Tayl. s.l. (S. degenii K. Muell. phases) - B (1-3); s.

S. curta (Mart.) Dum. - B (1); r; O'.

S. gymnostomophila Kaal. - B (1-2); s; gem.

S. matveyevae Potemkin - B (3); ls; gem, O'.

S. mucronata Buch ssp. praetervisa (Meyl.) Schust. - B (1-2); s; gem.

S. nemorea (L.) Grolle ssp. crassiretis (Bryhn) Potemkin - B (2-3); lc; gem.

S. obcordata (Berggr.) S. Arnell. - B (2-3), K; s; gem.

S. paludicola Loeske \& K. Muell. - B (2-3); 1s.

S. scandica (H. Arnell. \& Buch) Macv. - B (2-3); r.

S. simmonsii Bryhn \& Kaal. - B (1-3); s.

S. undulata (L.) Dum. - B (1); r.

S. zemliae S. Arnell - B (2-3); s; gem.

\section{Cephaloziaceae}

Cephalozia bicuspidata (L.) Dum. subsp. ambigua (C. Mass.) Schust. - B (2); r.

- subsp. bicuspidata - B (1-3); s.

Odontoschisma macounii (Aust.) Und. - B (3); s.

Cephaloziellaceae

Cephaloziella arctica Bryhn \& Douin - B (1-3); c; gem, per. 
C. arctogena (Schust.) Konst. - B (1); r; per.

C. grimsulana (Gott. \& Rabenh.) Lacout - B $(1,3)$, $\mathrm{K}$; s; gem.

C. uncinata Schust. - B (1-2); r.

ARNELLIACEAE

Arnellia fennica (Gott.) Lindb. - B (1); r.

Plagiochilaceae

Plagiochila porelloides (Nees) Lindenb. - B (1); s.

PTILIDIACEAE

Ptilidium ciliare (L.) Hampe - B (1-3); c.

Radulaceae

Radula prolifera $\mathrm{H}$. Arnell - B (1-3); s.

An analysis of this list shows the high dominance of the families Jungermanniaceae Reichenb. s.l. (18 species, 17 belong to the Lophozioideae Macv.) and Scapaniaceae Migula (12 species). Both families comprise 30 species, or $61,2 \%$ of the known flora. In spectrum of the genera the dominance of Scapania (12 species) and $\mathrm{LO}^{-}$ phozia (8) is obvious as well. Most of present records are based on the materials from the southern island of the archipelago,Bol'shevik Island. Only four species are known from Komsomolets Island. There are no species which are characteristic for Komsomolets Island only. The majority of species occur sporadically (s) or rare (r) on the territory under research. Only 8 species are distinguished as common in diverse habitats (c). Cephaloziella arctica, Gymnomitrion corallioides, G. concinnatum, and Tritomaria quinquedentata are most active of them. It is remarkable that none species of Scapania or Lophozia is common on the territory. They seem to be "ecological specialists" in the studied area. Many (15) species were found with gemmae, 7 - with perianth and two species of Gymnomitrion were collected with mature capsules. It is noteworthy that some species of Scapania show partial ( $S$. brevicaulis, S. gymnostomophila, S. nemorea subsp. crassiretis) or complete (S. brevicaulis) suppression of gemma production that is uncommon for their populations from the other places.

A NEW SPECIES OF SCAPANIA, ITS TAXONOMIC POSITION AND DIFFERENTIATION

Scapania matveyevae Potemkin, sp. nov. (Fig. 2)

Scapaniae nemoreae subsp. crassireti similis, sed ab hac gemmis bicellularibus decoloratis plus minusque angulosis, cellulis terminatis dentium foliorum brevioribus, cellulis foliorum majoribus, guttis oleosis pluribus cito dilabentibus distinguitur.

Plants 2-4 mm wide x 30-80 mm long, olivegreen to purplish brown and blackish fuscous, with solitary ventral intercalary branches. Cortex 2-3(-4)-stratose, of strongly thick-walled cells with deeper pigmented middle lamellae, \pm interrupted ventrally by a few tiers of cells with hardly thickened walls; outer cortical cells sporadically bleached, stronger thick-walled than internal cells, \pm flattened tangentially; mycorrhizal infection absent in apical stem sectors, sporadically present in basal sectors. Leaves short-dentate in their distal and median portions to subentire. Dorsal lobe 0.65-0.8 the ventral, subparallel to slightly divergent with it, divergent from stem at angle ca. 10-35(-40) ${ }^{\circ}$, rounded quadrangular to oblique reniform and cordate, strongly convex to concave in some forms, apiculate to obtusely pointed, usually strongly extended beyond the further edge of stem, x (1.13-)1.2-1.6 as wide as long, arcuately inserted, short decurrent. Ventral lobe divergent with stem at angle ca. $35-60^{\circ}$, rounded oblong, convex to occasionally concave, strongly broadly recurved, triangulary pointed to broadly rounded distally, x 1.0-1.35 as wide as long, \pm definitely decurrent below keel insertion, not hyaline and often purplish pigmented near base margin. Keel \pm slightly rounded and multistratose basally, acute and 2-3-stratose medially and distally, 0.3-0.4 ventral lobe length, straight to indistinctly arched; wing broad, entire to crispate, occasionally with solitary short teeth. Marginal teeth 1(-3) cells at base, 1(-5) cells long, with 1(-2)-celled uniseriate ends, with bleached terminal tooth cells $\times 1.3-1.8$ as long as wide, to $\mathrm{x} 2.25$ as long as wide on leaves near gemmi parous regions. Marginal cells distally ca. $17-32$ x 20-48 $\mu \mathrm{m}$, slightly thick-walled. $M e^{-}$ dian cells of free ventral lobe ca. 20-34 x (20)25-38(-45) $\mu \mathrm{m}, \pm$ thin-walled with mostly medium-sized, bulging to acute trigones. Basal cells of ventral lobe not form definite extensive area of lax tissue, ca. 30-35(-42) x 60-70(-90) $\mu \mathrm{m}, \pm$ thin-walled, occasionally with small intermediate thickenings, with small to large, bulging to acute trigones, which usually smaller than trigones in median cells. Cell walls of deep pigmented leaves with definite dark pigmented 


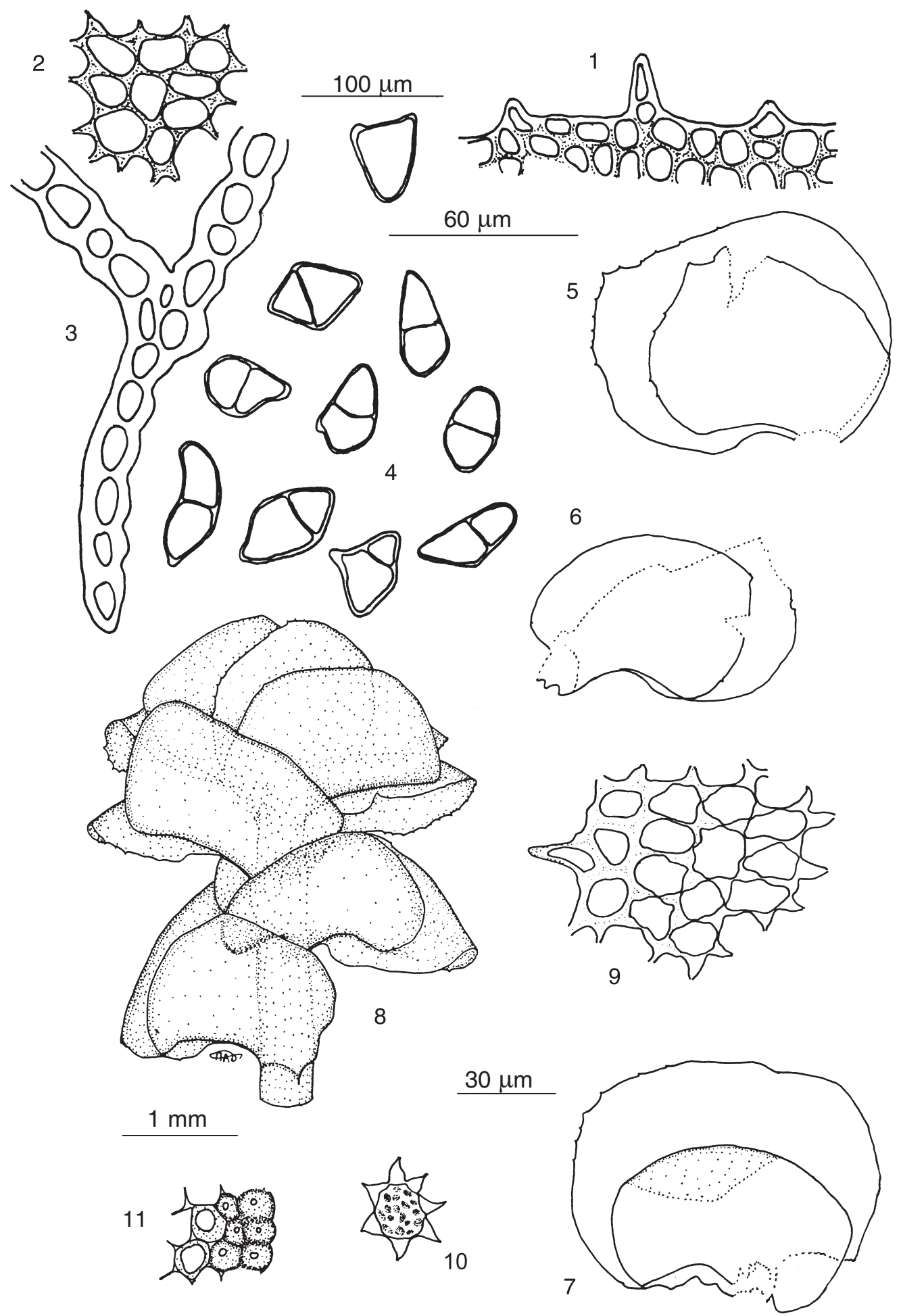

Fig. 2. Scapania matveyevae Potemkin (all from holotype, LE). 1 - apical sector of internal margin of ventral lobe; 2 - median cells of ventral lobe; 3 - keel cross section, medially; 4 - gemmae; 5-7 - leaves; 8 - upper shoot sector, antical aspect; 9 - sector of postical margin of ventral lobe, medially; 10 - median cell of ventral lobe with most papillose cuticle; 11 - stem cross section, lateral sector. Scale bars: $100 \mu \mathrm{m}$ for $1-3 ; 30 \mu \mathrm{m}$ for $4 ; 1 \mathrm{~mm}$ for 5-8; $60 \mu \mathrm{m}$ for $9-11$ 
middle lamella. Oil bodies nonpersistent, (5-)811(-16) per median cells, rounded to oval, finely granulate, 4-7 $\mu \mathrm{m}$ in diam. to $3-5 \times 5-8 \mu \mathrm{m}$. Cuticle smooth to \pm coarsely punctate papillose. Gemmae rare, (1-)2-celled, colorless to sporadically yellowish, thin-walled, variable in shape, elliptic, ovate, trigonal and rectangular-polygonal, with slightly to moderately thickened and projected angles, (17-)20-23(-26) x (24-)28$37(-40) \mu \mathrm{m}, \mathrm{x}(1.3-) 1.4-1.55(-1.85)$ as long as wide; gemmi parous leaves not modified from gemma production but terminal cells of their teeth may be stronger elongated than on ordinary leaves. Dioicous. Androecia hardly defined from sterile shoot sectors, of 5-10 pairs of 1-3androus bracts; paraphyses solitary, large to small, often lanceolate. Female plants unknown.

Specimens examined: 1) Holotype: Severnaya Zemlya Archipelago, Southern Part of Bol'shevik Island. Vicinity of "Solnechnaya" Polar Station, 78 $13^{\prime}$ N $103^{\circ} 15^{\prime}$ E, sea shore plain, herb-moss bog at rock ridge foot, among Ptilidium, Tritomaria quinquedentata, Aneura, with Scapania paludicola, 1.IX.1998 Matveyeva n. 73 [labelled as holotype] (LE; isotype, H); 2) paratype: the same place, among Tritomaria quinquedentata, Ptilidium ciliare, Cephaloziella arctica, Lophozia major, Barbilophozia quadriloba, Aneura, 1.IX.1998 Matveyeva n. 73 [labelled as paratype] (LE).

Scapania matveyevae appears to be an arctic polyploid species ("normal" Scapania never develop such the large cells characteristic of $S$. matveyevae). It is probably derived from $S$. nemorea subsp. crassiretis. It differs from the latter in (1-)2-celled (2) \pm angulate (3) mostly nonpigmented gemmae; (4) shorter terminal tooth cells of leaves (x 1.3-1.8 vs. x 2-3 as long as wide); (5) considerably larger leaf cells; (6) not persistent (7) more numerous oil bodies ((5-)8-11(-15) vs. (2-)3-6(-8) per cell); (8) broader ventral lobes (1.0-1.35 vs. 0.65-1.0(1.1) as wide as long); (9) normally broad \pm crispate keel wing.

I consider reasonable to distinguish $S$. matveyevae as an advanced member of the sectio Nemorosae on the basis of the following similarities and assumptions connected with its possibly polyploid origin: similar with $S$. nemorea subsp. crassiretis (1) habit, (2) shape of dorsal lobe, (3) stem anatomy, (4) pigmen- tation pattern, (5) leaf areolation and (6) tooth distribution; (7) proportionally more numerous oil bodies of similar size; (8) larger cells; and (9) broader wing of leaf keel in comparison with the latter. 2-celled angulate gemmae and shorter terminal tooth cells probably may represent character modifications resulted from some kind of polyploidy. Origin of $S$. matveyevae from $S$. nemorea subsp. crassiretis seems possible also because of very uncommon abundance of the latter in the herb-moss bog at rock ridge foot where the new species was collected.

Besides $S$. nemorea subsp. crassiretis, $S$. matveyevae may be confused also with $S$. serrulata Schust. and S. simmonsii Bryhn \& Kaal. $S$. matveyevae may be distinguished from $S$. serrulata on the basis of (1) larger size of plants (2-4 mm wide $\mathrm{x} 30-80 \mathrm{~mm}$ long vs. $1.8-3.1 \mathrm{~mm}$ wide x 10-25 mm long); (2) different shape of dorsal lobes, which are (a) rounded quadrangular to cordate and oblong reniform (vs. \pm reniform and rounded oblong), (b) apiculate to obtusely pointed (vs. blunt), (c) considerably broader and (d) short decurrent (vs. not decurrent); (3) different shape of ventral lobes, which are (a) strongly broadly recurved (vs. strongly convex) and (b) broader (1.0-1.35 vs. 0.74-0.91 as wide as long); (4) shorter keels (0.3-0.4 vs. 0.45-0.65 ventral lobe length); (5) mostly 2-celled (6) larger gemmae (20-23 x 28$37 \mu \mathrm{m}$ vs. $16-18 \times 22-27 \mu \mathrm{m})$ and (7) cortical cells with deep pigmented middle lamellae.

Confusion of $S$. matveyevae with $S$. simmosii is possible mostly because of strongly broadly recurved leaves of both species providing their similar appearance. $S$. matveyevae is distinct from $S$. simmonsii in (1) larger cells with (2) smaller trigones; (3) smaller dorsal lobes; (4) smooth to slightly papillose cuticle occurring rarely in $S$. simmonsii; (5) more numerous oil bodies ( (5-)8-11(-15) vs. 3-5(-7) per median leaf cell); (6) broad wing of the leaf keels; (6) leaf lobes which are mostly wider than long (vs. about as wide as long).

\section{ACKNOWLEDGMENTS}

I am grateful to Dr. Nadezhda V. Matveyeva for reading of the manuscript and her suggestions to improve English. Help of Dr. Alexei A. Oskolski with Latin translation is highly appreciated. Mr. Alexey P. Krylov is thanked for 
computer assistance valuable for figure preparation. The study was supported in part by grant 97-04-49828 of Russian Fund of Basic Research- es and program GNTP of Russia "Complex Exploration of oceans, seas, Arctic and Antarctic" (subdiv. $05 / 09$ ).

\section{LITERATURE CITED}

[ANDREEV, M.P., O.M. AFONINA \& A.D. POTEMKIN] АНДРЕЕВ, М.П., АФОНИНА, О.М., А.Д. ПОТЕМКИН 1993. Мохообразные и лишайники островов Комсомолец и Большевик (архипелаг Северная Земля) - [Bryophytes and lichens of the Komsomolets and Bol'shevik Islands (The Severnaya Zemlya Archipelago)] Бот.Журн.[Bot. Zhurn.] 78(2): 69-79.

[KONSTANTINOVA, N.A., A.D. POTEMKIN \& R.N. SCHLJAKOV] КОНСТАНТИНОВА, Н.А., ПОТЕМКИН, А.Д., Р.Н. ШЛЯКОВ 1992. Список печеночников и антоцеротовых территории бывшего СССР [Check-list of the Hepaticae and Anthocerotae of the former USSR] - Arctoa 1(1-2): 87-127.
[POTEMKIN, A.D. ] ПОТЕМКИН, А.Д. 1999. К флоре печеночников острова Большевик (архипелаг Северная Земля). - [Tо the liverwort flora of the Bol'shevik Island (Severnaya Zemlya Archipelago)] Новости сист. низи. pacm. [Novosti Sist. Nizsh. Rast.] 33: 185-190.

[SAVICZ, L.I.] САВИЧ, Л.И. 1936. Мхи архипелага Франца-Иосифа, Северной Земли и о. Визе, собранные В. П. Савичем во время полярной экспедиции 1930 г. на ледоколе “Г. Седов”. - [Mosses of FranzJoseph Archipelago, Severnaya Zemlya and Island of Vize collected by V. P. Savicz during polar expedition of 1930 on icebreaker "G. Sedov"] Tp. Бот. инст. AH CCCP [Tr. Bot. Inst. AN SSSR] Ser. 2, 3: 505-578. 